\title{
Effect of Pre-harvest Calcium Chloride and Salicylic Acid Spray on Morphological and Biochemical Traits of Guava (Psidium guajava)
}

Lochan Kaushik $^{1}$, Rahul Kumar², Dilip Kumar Reddy², Prashant Kaushik ${ }^{3 *}$

${ }^{1}$ Department of Horticulture, Chaudhary Charan Singh Haryana Agricultural University, Hisar, Haryana, India

${ }^{2}$ Sardar Vallabhbhai Patel University of Agriculture and Technology, Meerut 250110, India ${ }^{3}$ Instituto de Conservación y Mejora de la Agrodiversidad Valenciana, Universitat Politècnica de València, 46022 Valencia, Spain

*Email: prashantumri@gmail.com

\begin{abstract}
Guava is a small, tropical fruit tree grown in various tropical and subtropical regions. Salicylic acid (SA) is a phenolic compound that enhances disease resistance and delays the fruit ripening process. Calcium is an essential cell component that delays ripening, particularly softening of the fruit. The effect of foliar spray of $\mathrm{CaCl}_{2}$, and $\mathrm{SA}$, on the physical and biochemical traits of guava was investigated in the present investigation. The application of $\mathrm{CaCl}_{2} 2 \%+\mathrm{SA} 2 \mathrm{mM}$ was more effective as compared with both when applied alone. The data were recorded on fruit set (\%), fruit weight $(\mathrm{g})$, fruit length $(\mathrm{cm})$, fruit diameter $(\mathrm{cm})$, fruit yield $(\mathrm{kg})$, ripening period (days), TSS, acidity, total sugar, ascorbic acid, nitrogen, phosphorus, potassium. $\mathrm{CaCl}_{2} 2 \%+\mathrm{SA} 2 \mathrm{mM}$ was showed better performance in all cases, followed by $\mathrm{SA} 2 \mathrm{mM}$ and $\mathrm{CaCl}_{2} 2 \%$. Overall, this work determines the influence on guava's essential traits by pre-harvest calcium chloride and salicylic acid.
\end{abstract}

Keywords: Guava, Spray, Calcium chloride, Salicylic acid, Traits

\section{Introduction}

Guava belonging to the myrtle family (Myrtaceae) is a common fruit cultivated in tropical and subtropical regions of the world as popular fruit. The guava is full of nutrients as iron, calcium, phosphorus and vitamins as ascorbic acid, pantothenic acid, vitamin A along niacin (Embaby and Hassan, 2015). The plant's durable qualities can withstand unfavourable 
climatic factors and increases under a broad selection of soil sorts (Dhaliwal and Singla 2002). It is ordinarily ingested new as a dessert fruit, or perhaps refined into juice, jam, jelly, nectar, and syrup (Jagtiani et al., 1988). Salicylic acid (SA), an all-natural plant hormone, increases tolerance against biotic stresses (Khan et al., 2012). It plays a good role in plant growth, ion uptake, and nutrient transport within the plant. SA is a phenolic compound (Shafiee et al., 2010), enhances disease resistance (Aghdam et al., 2009), and delays fruit ripening (Srivastava and Dwivedi, 2000). SA governs processes, such as heat generation in plants, disease resistance, seed germination, gender polarisation, and ethylene production (Srivastava and Dwivedi, 2000; Ding and Wang, 2003; Zhang et al., 2003). The amount of SA synthesis increased, or stress tolerance mechanisms triggered by increasing the SA concentration in the plant by external treatments have been calculated in stress-tolerant plants. (Ding et al., 2001; Hayat et al., 2010).

Salicylic acid increases shoot length, the number of leaves and leaf area in guava (Jamali et al. 2011; Ram et al., 2016). Foliar spray of SA significantly increased vegetative growth, several flower clusters in strawberry cultivars (Lo'ay and El Khateeb, 2011; Mohamed et al., 2017). Salicylic acid treatment increases total phenol content in fruit (Giménez et al., 2014; Erogul and Özsoydan, 2020).

As a portion of the cellular system, calcium plays a crucial function in preserving the cell wall (Fry 2004; Hepler and Winship 2010). Ca delays the process of maturation as well as increases longevity (Shehata et al., 2009). $1 \% \mathrm{Ca}\left(\mathrm{NO}_{3}\right)_{2}$ treated fruit has decreased spoilage, ascorbic acid and TSS by two times under context conditions appropriately (Goutam et al., 2010). $\mathrm{CaCl}_{2}$ modulates improvements in fresh guava and increases guava consistency during storage (Chawla et al., 2010). The postharvest application of $\mathrm{CaCl}_{2}(2 \%)$ improves guava fruits' shelf life with less weight loss and high quality (Mahajan et al., 2011).

A combination treatment of $\mathrm{CaCl}_{2}$ and $\mathrm{SA}$ improves plant defense systems. It enhances the storage period of apples (Zhao and Wang, 2015), increase fruit firmness, and reduce percentages of weight losses and fruit decay during storage (Kazemi et al., 2011; Mostafa and Sultan, 2018). Keeping this in view, the investigation was carried out to study the effect of $\mathrm{CaCl}_{2}, \mathrm{SA}$ alone and in combination on physical and biochemical parameters of guava.

\section{Materials and methods}


The present study was carried out at Agriculture Research Farm, Haryana, India, coordinates at $29.94^{\circ} \mathrm{N} 76.89^{\circ} \mathrm{E}$ during $2018-19$. The experiment was conducted on 5-year-old guava trees of variety Hisar Safeda, the plants were procured from the CCS Haryana Agricultural University, Hisar, India. The experiment was carried out in an entirely randomized block design composed of 3 replicates and the soil characters are defined, elsewhere (Kaushik, 2020). The investigation was carried out with four treatments with three replications. The treatments were comprised of Calcium chloride $\left(\mathrm{CaCl}_{2}\right) @ 2 \%$, Salicylic acid (SA) $2 \mathrm{mM}$ and $\mathrm{CaCl}_{2} 2 \%+\mathrm{SA}$ $2 \mathrm{mM}$ along with control. At the colour stage (20 days before harvest) in the 2 nd week of December, treatments were applied in liquid spray until the leaves were completely soaked. Each treatment consisted of 5 plants in a single replication, and there were 3 replications of each treatment.

The data were recorded on fruit set $(\%)$, fruit weight $(\mathrm{g})$, fruit length $(\mathrm{cm})$, fruit diameter (cm), fruit yield (kg), ripening period (days), TSS, acidity, total sugar, ascorbic acid, nitrogen, phosphorus, potassium. With the assistance of an Erma Hand Refractometer (Napoca, Japan), the total soluble solids (TSS) content was measured and expressed at $20{ }^{\circ} \mathrm{C}$ temperature. Ascorbic acid, total sugar and titratable acidity were estimated by the method described by AOAC (1990).

\section{Data analysis}

Means of each replication was subjected for the estimation of ANOVA. Duncan's multiple range test (DMRT) was used as the posthoc analysis to estimate the mean differences. Pearson`s linear correlations were calculated for the determination of correlation among the traits. All numerical analysis was performed using JASP (version 0.14.1) software program.

\section{Results}

Maximum fruit set (84.22) was observed in treatment $\mathrm{CaCl}_{2} 2 \%+\mathrm{SA} 2 \mathrm{mM}$ followed by the $\mathrm{CaCl}_{2} 2 \%$ (72.33) and SA $2 \mathrm{mM}$ (79.67) as compare by the control 76.11 (Table 1). In case of fruit weight, highest was observed in the treatment $\mathrm{CaCl}_{2} 2 \%+\mathrm{SA} 2 \mathrm{mM}(67.68 \mathrm{~g})$ followed by the $\mathrm{CaCl}_{2} 2 \%(60.66 \mathrm{~g})$ and SA $2 \mathrm{mM}(60.02 \mathrm{~g})$ as compare to the control (44.78) (Table 1). The treatment $\mathrm{CaCl}_{2} 2 \%+\mathrm{SA} 2 \mathrm{mM}$ was more effective on the fruit weight. Maximum fruit length $(5.92 \mathrm{~cm})$ was observed in the case of treatment $\mathrm{CaCl}_{2} 2 \%+\mathrm{SA} 2 \mathrm{mM}$ followed by SA $2 \mathrm{mM}(5.73)$ and $\mathrm{CaCl}_{2} 2 \%$ (5.41) as compare to the control (4.83 cm) (Table 1). Fruit diameter 
$(5.68 \mathrm{~cm})$ was maximum in the treatment of $\mathrm{CaCl}_{2} 2 \%+\mathrm{SA} 2 \mathrm{mM}$ followed by the SA $2 \mathrm{mM}$ (5.53) and $\mathrm{CaCl}_{2} 2 \%$ (5.28) as compare to the control $4.96 \mathrm{~cm}$ (Table 1). Highest fruit yield (77 $\mathrm{kg}$ ) was recorded in case of $\mathrm{CaCl}_{2} 2 \%+\mathrm{SA} 2 \mathrm{mM}$ spray followed by $\mathrm{SA} 2 \mathrm{mM}(62.78 \mathrm{~kg})$ and $\mathrm{CaCl}_{2} 2 \%(57.56 \mathrm{~kg})$ as compare to control $(53.11 \mathrm{~kg})($ Table 1$)$.

Minimum ripening day (11.44) was observed in case of $\mathrm{CaCl}_{2} 2 \%+\mathrm{SA} 2 \mathrm{mM}$ spray followed by SA $2 \mathrm{mM}(12.44)$ and $\mathrm{CaCl}_{2} 2 \%$ (18.56) as compare to the control (22.22) (Table 2). Highest TSS (11.12) was observed in case of $\mathrm{CaCl}_{2} 2 \%+\mathrm{SA} 2 \mathrm{mM}$ spray followed by SA $2 \mathrm{mM}$ (10.87) and $\mathrm{CaCl} 22 \%(10.16)$ as compare to the control (8.94) (Table 2). Minimum acidity (0.44) was recorded in case of $\mathrm{CaCl}_{2} 2 \%+\mathrm{SA} 2 \mathrm{mM}$ spray followed by SA $2 \mathrm{mM}(0.47)$ and $\mathrm{CaCl}_{2} 2 \%(0.49)$ as compare to the control (0.51) (Table 2). Highest sugar recorded in case of $\mathrm{CaCl}_{2} 2 \%+\mathrm{SA} 2 \mathrm{mM}$ (7.20) spray followed by SA $2 \mathrm{mM}$ (6.86) and $\mathrm{CaCl}_{2} 2 \%$ (6.24) as compare to the control (5.50). Highest ascorbic acid (8.29) recorded in case of $\mathrm{CaCl}_{2} 2 \%+\mathrm{SA} 2 \mathrm{mM}$ spray followed by SA $2 \mathrm{mM}(8.01)$ and $\mathrm{CaCl}_{2} 2 \%$ (7.54) as compare to the control (7.24) (Table 2).

\section{Correlation}

Correlation studies were revealed that fruit set content was positively correlated with the total sugar, ascorbic acid, nitrogen and phosphorous (Figure 1). Fruit weight was positively correlated with the fruit length, fruit diameter, TSS, total sugar, ascorbic acid, and potassium (Figure 1). In comparison, a significant and positive correlation was determined between the fruit weight, fruit diameter, TSS, total sugar, ascorbic acid, and potassium with that of fruit length. Fruit diameter was positively correlated with the fruit weight, fruit length, TSS, total sugar, ascorbic acid, and potassium (Figure 1).

Moreover, the ripening period was significant and negatively correlated with all parameters except acidity. Furthermore, TSS was determined to be positively correlated with the fruit weight, fruit length, fruit diameter, total sugar, ascorbic acid, and potassium whereas, the acidity was correlated with the ripening period (Figure 1). Moreover, total sugar was positively correlated with fruit set, fruit weight, fruit length, fruit diameter. The positive correlation was determined between ascorbic acid and fruit set, fruit weight, fruit length, fruit diameter, TSS, total sugar, nitrogen, phosphorous (Figure 1). Nitrogen was significant and positively correlated with fruit set, fruit yield, whereas phosphorous was correlated with fruit set, fruit yield, nitrogen, 
ascorbic acid. Moreover, potassium was positively correlated with fruit weight, fruit length, fruit diameter, TSS, total sugar, ascorbic acid (Figure 1).

Table 1: Effect of $\mathrm{CaCl}_{2}$, SA alone and in combination on yield parameters of guava.

\begin{tabular}{|l|l|l|l|l|l|}
\hline Treatments & Fruit set & $\begin{array}{l}\text { Fruit } \\
\text { weight }(\mathrm{g})\end{array}$ & $\begin{array}{l}\text { Fruit length } \\
(\mathrm{cm})\end{array}$ & $\begin{array}{l}\text { Fruit diameter } \\
(\mathrm{cm})\end{array}$ & $\begin{array}{l}\text { Fruit yield } \\
(\mathrm{kg})\end{array}$ \\
\hline $\mathrm{CaCl}_{2} 2 \%$ & $72.33 \mathrm{c}$ & $60.66 \mathrm{~b}$ & 5.41 & $5.28 \mathrm{~b}$ & $57.56 \mathrm{~b}$ \\
\hline $\mathrm{SA} 2 \mathrm{mM}$ & $79.67 \mathrm{~b}$ & $60.02 \mathrm{~b}$ & 5.73 & $5.53 \mathrm{ab}$ & $62.78 \mathrm{ab}$ \\
\hline $\mathrm{CaCl}_{2} 2 \%+\mathrm{SA} 2 \mathrm{mM}$ & $84.22 \mathrm{a}$ & $67.68 \mathrm{a}$ & $5.92 \mathrm{a}$ & $5.68 \mathrm{a}$ & $77.00 \mathrm{a}$ \\
\hline $\mathrm{Control}$ & $76.11 \mathrm{bc}$ & $44.78 \mathrm{c}$ & $4.83 \mathrm{c}$ & $4.96 \mathrm{c}$ & $53.11 \mathrm{~b}$ \\
\hline $\mathrm{CV}$ & 2.64 & 3.40 & 3.20 & 2.43 & 11.98 \\
\hline
\end{tabular}

*values in a column followed by the same letter are not significantly different, $\mathrm{p} \leq 0.05$, LSD.

Table 2: Effect of $\mathrm{CaCl}_{2}$, SA alone and in combination on bio-chemical characters of guava.

\begin{tabular}{|l|l|l|l|l|l|}
\hline Treatments & Ripening day & $\begin{array}{l}\text { TSS } \\
\left({ }^{\circ} \text { Brix }\right)\end{array}$ & Acidity (\%) & Total sugar & $\begin{array}{l}\text { Ascorbic } \\
\text { acid (mg/100 } \\
\text { g Pulp) }\end{array}$ \\
\hline $\mathrm{CaCl}_{2} 2 \%$ & $18.56 \mathrm{~b}^{*}$ & $10.16 \mathrm{~b}$ & $0.49 \mathrm{a}$ & $6.24 \mathrm{~b}$ & $7.54 \mathrm{c}$ \\
\hline $\mathrm{SA} 2 \mathrm{mM}$ & $12.44 \mathrm{c}$ & $10.87 \mathrm{a}$ & $0.47 \mathrm{~b}$ & $6.86 \mathrm{a}$ & $8.01 \mathrm{~b}$ \\
\hline $\mathrm{CaCl} 2 \%+\mathrm{SA} 2 \mathrm{mM}$ & $11.44 \mathrm{c}$ & $11.12 \mathrm{a}$ & $0.44 \mathrm{c}$ & $7.20 \mathrm{a}$ & $8.29 \mathrm{a}$ \\
\hline $\mathrm{Control}$ & & & & & \\
\hline $\mathrm{CV}$ & $22.22 \mathrm{a}$ & $8.94 \mathrm{c}$ & $0.51 \mathrm{a}$ & $5.50 \mathrm{c}$ & $7.24 \mathrm{~d}$ \\
\hline
\end{tabular}

*values in a column followed by the same letter are not significantly different, $\mathrm{p} \leq 0.05$, LSD.

Table 3: Effect of $\mathrm{CaCl}_{2}$, SA alone and in combination on nutrients of leaf in guava.

\begin{tabular}{|l|l|l|l|}
\hline Treatments & Nitrogen (\%) & $\begin{array}{l}\text { Phosphorous } \\
(\%)\end{array}$ & Potassium (\%) \\
\hline
\end{tabular}




\begin{tabular}{|l|l|l|l|}
\hline $\mathrm{CaCl}_{2} 2 \%$ & $1.76 \mathrm{~b}$ & $0.12 \mathrm{c}$ & $0.75 \mathrm{a}$ \\
\hline $\mathrm{SA} 2 \mathrm{mM}$ & $1.79 \mathrm{~b}$ & $0.13 \mathrm{~b}$ & $0.79 \mathrm{a}$ \\
\hline $\mathrm{CaCl}_{2} 2 \%+\mathrm{SA} 2 \mathrm{mM}$ & $1.88 \mathrm{a}$ & $0.15 \mathrm{a}$ & $0.78 \mathrm{a}$ \\
\hline Control & $1.75 \mathrm{~b}$ & $0.12 \mathrm{c}$ & $0.63 \mathrm{~b}$ \\
\hline $\mathrm{CV} \%$ & 1.37 & 2.64 & 6.12 \\
\hline
\end{tabular}

*values in a column followed by the same letter are not significantly different, $\mathrm{p} \leq 0.05$, LSD.

The highest percentage of leaf $\mathrm{N}$ content was recorded for the treatment comprising of $\mathrm{CaCl}_{2} 2 \%$ + SA $2 \mathrm{mM}$, followed by the treatment with SA $2 \mathrm{mM}$ and $\mathrm{CaCl}_{2} 2 \%$ (Table 3 ). Similarly, the highest percentage of $\mathrm{P}$ content was determined for the treatment $\mathrm{CaCl}_{2} 2 \%+\mathrm{SA} 2 \mathrm{mM}$, followed by the treatments with $\mathrm{SA} 2 \mathrm{mM}$ and $\mathrm{CaCl}_{2} 2 \%$ (Table 3 ). Whereas the $\mathrm{K}$ content was highest in the treatment SA $2 \mathrm{mM}$, the least values were recorded in control (Table 3).

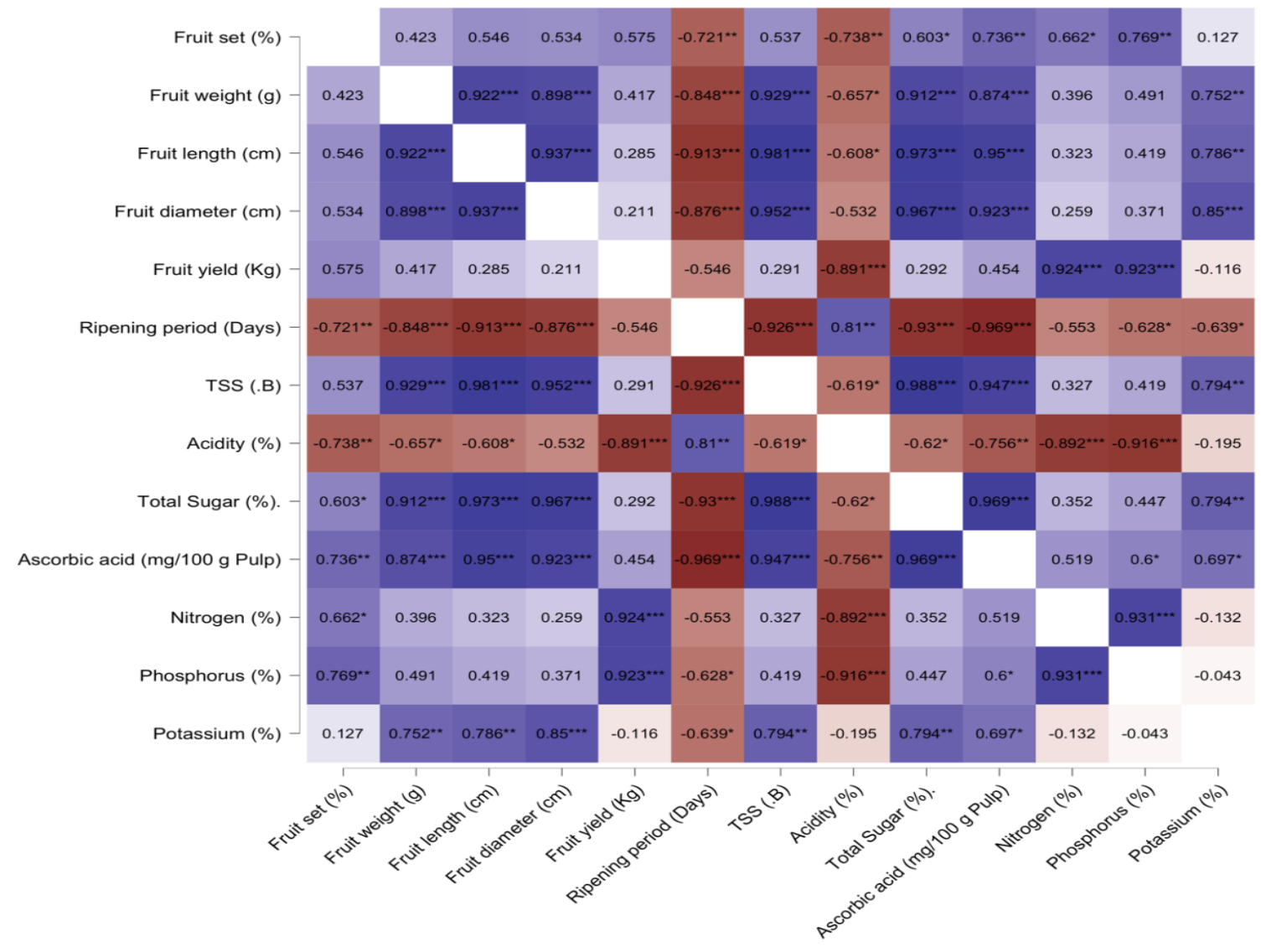


Figure 1. Pearson's linear correlation among the traits studied in guava under the influence of $\mathrm{CaCl}_{2}$ and $\mathrm{SA}$.

Fruit set was observed maximum in the treatment $\mathrm{CaCl}_{2} 2 \%+\mathrm{SA} 2 \mathrm{mM}$ application followed by SA $2 \mathrm{mM} \mathrm{CaCl}_{2} 2 \%$. Similarly, Ram et al., (2016) reported that maximum fruit set per cent was found in SA @ 100 ppm. Similar result of SA on fruit set was also recorded by Nicholas and Embree (2004) and Liao et al. (2006) in apple and citrus, respectively. Fruit weight, fruit length and fruit diameter were highest recorded in the combination of $\mathrm{CaCl}_{2} 2 \%+\mathrm{SA}$ 2mM. Erogul and Özsoydan (2020) also reported that fruit weight, fruit width and fruit length were increased with the application of SA. The combined effect of $\mathrm{CaCl}_{2} 2 \%+\mathrm{SA}$ $2 \mathrm{mM}$ gave the highest fruit yield, followed by SA $2 \mathrm{mM}$. Our observations were similar with the findings of Kazemi (2013). Highest TSS, ascorbic acid was observed in the case of $\mathrm{CaCl}_{2} 2 \%+\mathrm{SA} 2 \mathrm{mM}$ spray followed by SA $2 \mathrm{mM}$ and $\mathrm{CaCl}_{2} 2 \%$ compared to the control. Zhao and Wang (2015) also reported the similar trend on total soluble solids content, titratable acidity content. Mirdehghan and Ghotbi (2014) also reported SA and $\mathrm{CaCl}_{2}$ application increases TSS. Qureshi et al., (2013) also described that $\mathrm{SA}+\mathrm{CaCl}_{2}$ treatment improved strawberry quality by significantly increasing ascorbic acid and total soluble solids contents, with a non-significant result for titratable acidity. The data revealed that the application of $\mathrm{CaCl}_{2} 2 \%+\mathrm{SA} 2 \mathrm{mM}$ significantly increased nitrogen, phosphorous, and potassium content compared to control. The increase of nitrogen and phosphorous were nonsignificant with the application of calcium chloride as compared to control (Kaushik et al., 2020b, 2020a). The results are also agreeing with the findings of Youssef et al., (2017).

\section{Conclusion}

The application of $\mathrm{CaCl}_{2} 2 \%+\mathrm{SA} 2 \mathrm{mM}$ was more effective and showed more fruit yield and fruit set followed by SA $2 \mathrm{mM}$ and $\mathrm{CaCl}_{2} 2 \%$. High TSS, total sugar and ascorbic acid was found in the combined effect of $\mathrm{CaCl}_{2} 2 \%+\mathrm{SA} 2 \mathrm{mM}$ followed by SA $2 \mathrm{mM}$ and $\mathrm{CaCl}_{2} 2 \%$. These observations revealed that the combined effect of SA $2 \mathrm{mM}$ and $\mathrm{CaCl}_{2} 2 \%$ was more effective.

\section{References}


Aghdam MS, Mostofi YM, Ghasemneghad AM. and Moghaddam FJ (2009). Effect of MeSA vapor treatment on the postharvest quality of Hayward Kiwifuit. in 6th Interntional Postharvest Symposium. Antalya,Turkey.

AOAC (1990) Official Methods of Analysis (12th Edn), Washington, DC, USA.

Chawla S, Devi R and Jain V (2018). Changes in physicochemical characteristics of guava fruits due to chitosan and calcium chloride treatments during storage. Journal of Pharmacognosy and Phytochemistry; 7(3): 1035-1044.

Dhaliwal GS and Singla R (2002). Studies on the time of anthesis and dehiscence in different genotypes of guava in winter and rainy season crops. Idian J Hort. 59:157-161.

Ding CK, Wang CY, Gross KC and Smith DL (2001). Reduction of chilling injury and transcript accumulation of heat shock proteins in tomato fruit by methyl jasmonate and methyl salicylate. Plant Science, 161: 1153-1159

Ding CK and Wang CY (2003). The dual effects of methyl salicylate on ripening and expression of ethylene biosynthetic genes in tomato fruit. Plant Science, 164, 589-596.

Embaby E, Hassan MK (2015). Decay of guava fruit (Psidium guajava Linn.) quality caused by some mold fungi. International Journal of Agricultural Technology, 11(3):713-730.

Erogul D and Özsoydan I (2020). Effect of pre-harvest salicylic acid treatments on the quality and shelf life of the 'Cresthaven' peach cultivar. Folia Hort. 32(2): 221-227.

Fry SC (2004) Primary cell wall metabolism: tracking the carriers of wall polymers in living cells. New Phytol 161:641-675

Giménez JM, Valverde JM, Valverdo MJ, Valero D, Guillén F, Martínez-Romero D, Serrano M and Casti 1 lo S (2014). Quality and antioxidant properties on sweet cherries as affected by preharvest salicylic and acetylsalicylic acids treatments. Food Chemistry, 160: 226-232.

Goutam M, Dhaliwal HS and Mahajan, B (2010). Effect of pre-harvest calcium sprays on postharvest life of winter guava (Psidium guajava L.). Journal of food science and technology, 47(5): 501-506. 
Hayat Q, Hayat S, Irfan M and Ahmad A (2010). Effect of exogenous salicylic acid under changing environment. A review. Environmental and Experimental Botany, 68:14-25.

Hepler PK and Winship LJ (2010). Calcium at the cell wall-cytoplast Interface. J. Integr. Plant Biol., 52 (2):147-160.

Jagtiani J, Chan HT and Sakai WS (1988). Tropical fruit processing. New York: Academic Press Inc. pp. 9-43.

Jamali B, Eshghi S and Tafazoli E (2011). Vegetative and reproductive growth of strawberry plants, cv. Pajaro affected by salicylic acid and nickel. J. Agr. Sci. Tech. 13:895-904.

Kaushik L, Gupta A, Singh D, Kaushik P, Chahal D, Mittal R, Kesh H (2020a). Effect of Foliar Feeding of Potash on Tree Growth Characters of Peach Cultivar Shan-e-Punjab. Int.J.Curr.Microbiol.App.Sci 9, 2452-2457.

Kaushik L, Singh D, Mittal R, Gupta A, Kant G, Singh S, Kaushik P (2020b). Effect of Pruning Intensity and Potash Spray on Biochemical Composition of Peach.

Int.J.Curr.Microbiol.App.Sci 9, 2468-2480.

Kaushik P (2020). Classification of Indian States and Union Territories based on their Soil Macronutrient and Organic Carbon Profiles. bioRxiv 2020.02.10.930586

Kazemi M, Aran M and Zamani S (2011). Effect of Calcium Chloride and Salicylic Acid Treatments on Quality Characteristics of Kiwifruit (Actinidia deliciosa cv. Hayward) During Storage. American Journal of Plant Physiology, 6: 183-189.

Kazemi M (2013). Foliar Application of Salicylic Acid and Calcium on Yield, Yield Component and Chemical properties of Strawberry. Bull. Env. Pharmacol. Life Sci., 2(11): 19-23

Khan NA, Nazar R, Iqbal N and Anjum NA (2012) Phytohormones and Abiotic Stress Tolerance in Plants. Springer, Berlin, Heidelberg.

Liao HL, Chen H and Chung KR (2006). Plant hormone inhibitors for reducing post bloom fruit drop of citrus. Proc.Fla.State. Soc., 119: 78-81. 
Lo'ay AA and El Khateeb AY (2011). Delaying Guava Ripening by Exogenous Salicylic Acid. $J$. Plant Production, 2 (5): 715 - 724.

Mahajan BVC, Brar KS, Ghuman BS, Boora RS (2011). Effect of Pre-Storage Treatments of Calcium Chloride and Gibberellic Acid on Storage Behaviour and Quality of Guava Fruits. Fresh Produce, 5 (1), 22-25.

Mirdehghan SH and Ghotbi F (2014). Effects of Salicylic Acid, Jasmonic Acid, and Calcium Chloride on Reducing Chilling Injury of Pomegranate (Punica granatum L.) Fruit. J. Agr. Sci.Tech. 16: 163-173

Mohamed RA, Al-Kharpotly Abdelbaset and Abd-Elkader DY (2017) Salicylic Acid Effects on Growth, Yield, and Fruit Quality of Strawberry Cultivars. Journal of Medicinally Active Plants 6, (2):1-11

Mostafa YS and Sultan MZ (2018). Calcium chloride combined with antioxidants increases keeping quality and limits postharvest decay of loquat fruit. Acta Hortic. 1194: 157-164.

Nicholas D and Embree C (2004). Blossom and fruit let thinners affected affect crop load, fruit weight, seed number and return bloom of 'Northern Spy' Apple. Hort. Sci. 39(6): 13091312.

Qureshi KM, Chughtai S, Qureshi US, Abbasi NA (2013). Impact of exogenous application of salt and growth regulators on growth and yield of strawberry. Pakistan J. Bot. 45: 11791185

Ram B, Mandal BK, Kumar U, Kumar, R and Kumar P (2016). Response of guava to boron and growth regulators spray. The Asian Journal of Horticulture, 11 (1): 146-150.

Shafiee M, Taghavi TS and Babalar M (2010). Addition of salicylic acid to nutrient solution combined with postharvest treatments (hot water, salicylic acid, and calcium dipping) improved postharvest fruit quality of strawberry. Scientia Horticulturae, 124: 40-45.

Shehata SA, Hashem MY, Emam MS and Rageh MA (2009). Effect of hot water and calcium chloride treatments on fresh cut sweet pepper during cold storage. Annals of Agricultural Science Moshtohor Journal, 47(3):445-455. 
Srivastava MK and Dwivedi UN (2000). Delayed ripening of banana fruit by salicylic acid. Plant Science, 158: 87-96.

Youssef SMS, Abd El-Hady SA, Abu El-Azm NAI and El-Shinawy MZ (2017). Foliar Application of Salicylic Acid and Calcium Chloride Enhances Growth and Productivity of Lettuce (Lactuca sativa). Egypt. J. Hort. 44 (1): 1-16

Zhang Y, Chen K, Zhang S and Ferguson I (2003). The role of salicylic acid in postharvest ripening of kiwifruit. Postharvest Biology and Technology, 28(1): 67-74.

Zhao Y and Wang C (2015). Effect of Calcium Chloride in Combination with Salicylic Acid on Post-harvest Freshness of Apples. Food Sci. Biotechnol. 24(3): 1139-1146. 